\title{
Studi Kelayakan Bisnis Pembuatan Pupuk Organik Cair Berbahan Dasar Limbah Ikan Lemuru
}

\author{
Rudy Vernando Silalahi ${ }^{1 *}$, Imam Zarkasyi ${ }^{2}$ \\ 1,2Program Studi Teknik Industri, Universitas Pelita Harapan, Tangerang, Indonesia \\ (*rudy.silalahi@uph.edu)
}

\begin{abstract}
Abstrak - Pertanian di Indonesia merupakan salah satu penyokong utama dalam mendukung ketahanan pangan. Diketahui jumlah kebutuhan pupuk organik adalah sebesar 12,4 juta ton, dibantu oleh perusahaan badan usaha milik negara, jumlah kebutuhan yang dapat dipenuhi adalah $10,8 \%$. Terdapat peluang besar untuk membuat bisnis pupuk organik cair berdasarkan jumlah kebutuhan yang ada. Sebelumnya, perlu dilakukan riset pasar dan studi kelayakan bisnis menggunakan aspek pasar dan pemasaran, aspek teknis dan operasional, aspek hukum dan manajemen, serta aspek keuangan. Riset pasar dilakukan dengan menyebarkan kuesioner pada komunitas petani organik. Aspek pasar \& pemasaran diperoleh hasil berupa tingginya permintaan dan kecilnya persaingan. Aspek teknis dan operasional diperoleh hasil uji coba pupuk dan lokasi bisnis. Aspek hukum diperoleh bentuk usaha, langkah, dan dokumen yang diperlukan. Aspek manajemen, diperoleh jumlah pekerja yang dibutuhkan dan deskripsi pekerjaannya. Pada aspek keuangan diperoleh data mencakup biaya yang dibutuhkan untuk memulai usaha dan hasil perhitungan penilaian investasi yang terdiri dari hasil payback period pada bulan Maret tahun pertama bisnis dijalankan mengalami keuntungan, IRR sebesar 473.83\% > MARR yakni 34,56\%, dan nilai NPV > 0 sebesar Rp 340,847,497. Berdasarkan empat aspek penilaian studi kelayakan bisnis dan perhitungan penilaian investasi, diambil kesimpulan bahwa bisnis pupuk organik cair dari ikan lemuru layak untuk dijalankan.
\end{abstract}

Kata kunci: ikan lemuru; IRR; NPV; pupuk organik cair; studi kelayakan bisnis

\section{PENDAHULUAN}

Indonesia terkenal dengan sumber daya alam dan berkah tanah yang dimiliki, khususnya di bidang pertanian. Sektor pertanian berperan besar dalam mendukung ketahanan pangan nasional. Untuk memperkuat fondasi dalam membantu pertumbuhan dan perkembangan pada sektor pertanian, pemerintah mendorong penggunaan pupuk organik sebagai faktor pendukung dalam mendukung pertumbuhan tanaman pada sektor pertanian di Indonesia. Hal ini bertujuan untuk menghasilkan tanaman yang lebih sehat dan bebas unsur kimiawi. Berdasarkan data Statistik Pertanian Organik Indonesia, setiap 1 hektar lahan pertanian membutuhkan setidaknya $500 \mathrm{~kg}$ pupuk organik dan setiap 1 hektar lahan holtikultura mebutuhkan setidaknya 2 ton pupuk organik, sedangkan serapan pupuk organik untuk kedua jenis pertanian hanya dapat menutup 624 ribu ton ketersediaan pupuk organik. Melalui salah satu perusahaan Badan Usaha Milik Negara (BUMN) yakni PT Pupuk Indonesia (Persero), besar kapasitas produksi yang dimiliki adalah 13,752,500 ton pupuk yang terbagi dalam beberapa jenis pupuk. Sedangkan untuk jenis pupuk organik, dibutuhkan sekitar 17 juta ton pupuk organik. Pada kenyataannya, jumlah pupuk organik yang dapat dipenuhi oleh perusahaan BUMN hanya sebesar $10,8 \%$ dari 17 juta ton saja. Persentase tersebut hanya mewakili kemampuan pemenuhan yang dimiliki oleh PT Pupuk Indonesia (Persero), tanpa menghitung pemenuhan oleh perusahaan bukan BUMN. Artinya, kapasitas produksi yang dimiliki PT Pupuk Indonesia (Persero) masih belum dapat menutupi kekurangan dalam memenuhi kebutuhan pupuk organik di Indonesia. Hal ini semakin ditegaskan dengan tingginya impor pupuk dalam kurun waktu 5 tahun terakhir dengan rata-rata impor pupuk adalah 7 juta ton per tahun. Di lain tempat, terdapat limbah jeroan dari ikan lemuru yang dihasilkan oleh usaha ikan kering. Limbah tersebut dibuang tanpa melihat sisi ekonomis yang dapat dihasilkan. Mengacu pada masalah pada pemenuhan pupuk organik untuk sektor pertanian di Indonesia, salah satu cara memanfaatkan limbah ikan adalah dengan mengubahnya menjadi pupuk organik cair. Hal ini sejalan dengan pernyataan dari Guru Besar Fakultas Perikanan dan Ilmu Kelautan Institut Pertanian Bogor pada webinar "Mendulang Rupiah Melalui Pemanfaatan Cangkang Kerang dan Kulit Ikan" yang menyatakan bahwa terdapat 30-40\% limbah berupa bagian ikan yang tidak digunakan dari proses pengolahan ikan. Di sekitar daerah penelitian yakni Situbondo, menurut data statistik perikanan Provinsi Jawa Timur 2019, terdapat banyak titik pelabuhan perikanan yang artinya, bahan baku untuk membuat pupuk organik cair berbahan dasar ikan lemuru dapat diperoleh dengan mudah. Penelitian ini dilakukan untuk melihat apakah bisnis pembuatan pupuk organik cair 
berbahan dasar ikan lemuru layak untuk dijalankan dengan berdasarkan aspek-aspek penilaian studi kelayakan usaha seperti aspek pasar \& pemasaran, aspek teknis \& operasional, aspek hukum \& manajemen, serta aspek keuangan. Pembuatan produk pupuk organik cair dari bahan dasar limbah ikan lemuru masih terbilang baru, dengan dilakukannya penilaian studi kelayakan bisnis untuk pembuatan pupuk organik cair dari bahan limbah ikan lemuru, individu maupun kelompok yang bermaksud untuk membangun usaha serupa dengan bahan baku yang memiliki kesamaan akan lebih yakin dengan usaha yang hendak dibuat karena sudah pernah dilakukan perhitungan dan penilaian sebelumnya serta lebih mengerti hal apa saja yang perlu dipersiapkan dalam membangun bisnis pembuatan pupuk organik khususnya pupuk organik cair.

\section{STUDI LITERATUR}

Dalam penelitian ini, studi literatur yang digunakan tidak hanya berasal dari teori dalam buku ajar namun juga berasal dari hasil jurnal penelitian dan laporan tugas akhir yang menjadi data pendukung untuk menguatkan hasil penelitian yang dilakukan. Data-data pendukung tersebut berasal dari:

Tabel 1

Data-Data Pendukung Penelitian

\begin{tabular}{|c|c|c|}
\hline No & Judul & Hasil \\
\hline 1 & $\begin{array}{l}\text { "Pembuatan Pupuk Organik Cair dari Limbah Jeroan } \\
\text { Ikan Cakalang (Katsuwonus pelamis)" (Suartini dkk, } \\
\text { 2018) }\end{array}$ & $\begin{array}{l}\text { Pembuatan POC dari jeroan ikan cakalang } \\
\text { memungkinkan untuk dilakukan dengan metode } \\
\text { bekasang }\end{array}$ \\
\hline 2 & $\begin{array}{l}\text { "Pembuatan Pupuk Cair dari Limbah Pengolahan } \\
\text { Ikan Tradisional" (Piri, 2017) }\end{array}$ & $\begin{array}{l}\text { Limbah cair ikan dapat digunakan sebagai bahan } \\
\text { pembuatan pupuk organik cair dan memiliki kandungan } \\
\text { NPK yang mencukupi }\end{array}$ \\
\hline 3 & $\begin{array}{l}\text { "Pemanfaatan Limbah Cair Ikan Tuna terhadap } \\
\text { Pertumbuhan Tanaman pakchoy dengan Wick System } \\
\text { Hydroponics" (Ali dkk, 2020) }\end{array}$ & $\begin{array}{l}\text { Penggunaan POC dari limbah cair ikan tuna } \\
\text { berpengaruh signifikan seperti jumlah daun, panjang } \\
\text { tanaman, panjang akar dan berat basah per tanaman } \\
\text { pada pertumbuhan tanaman pakchoi }\end{array}$ \\
\hline 4 & $\begin{array}{l}\text { "Analisis Kelayakan bisnis Pupuk Organik (Studi } \\
\text { Kasus Rumah Kompos di Gapoktan Suka Hasil Desa } \\
\text { Cintaasih Kecamatan Cingambul Kabupaten } \\
\text { Majalengka)" (Apiat \& Dinar, 2016) }\end{array}$ & $\begin{array}{l}\text { Secara aspek non-finansial menyatakan bisnis layak } \\
\text { karena adanya ketersediaan bahan baku, metode } \\
\text { pengomposan dan lokasi strategis. Aspek finansial } \\
\text { menyatakan layak dengan hasil NPV }>0 \text { sebesar } \\
254.164 .920 \text {, Net B/C }>1 \text { sebesar } 9,6 \text {, IRR sebesar } \\
77 \% \text { dimana IRR lebih besar dari discount factor (rate) } \\
\text { yang berlaku sebesar } 9,5 \text { persen dengan periode } \\
\text { pengembalian (payback period) } 4 \text { tahun }\end{array}$ \\
\hline 5 & $\begin{array}{l}\text { "Analisis Kelayakan Bisnis Pupuk Organik (PO) } \\
\text { Curah" (Pardani \& Sutriana, 2018) }\end{array}$ & $\begin{array}{l}\text { Usaha pupuk organik secara finansial dan aspek } \\
\text { pendukung lainnya dinyatakan layak untuk dijalankan } \\
\text { dan mengalami keuntungan }\end{array}$ \\
\hline 6 & $\begin{array}{l}\text { "Analisis Kelayakan dan Strategi Pengembaangan } \\
\text { Usaha Pupuk Organik (Studi Kasus: Desa Mekar } \\
\text { Sari, Kecamatan Pulau Rakyat, Kabupaten Asahan, } \\
\text { Propinsi Sumatera Utara)" (Fransiska Putri, 2019) }\end{array}$ & $\begin{array}{l}\text { Analisis yang dilakukan dengan memperhatikan aspek } \\
\text { finansial dan didukung dengan formulasi strategi } \\
\text { menggunakan matriks SWOT menunjukkan bahwa } \\
\text { usaha pupuk organik layak untuk dijalankan }\end{array}$ \\
\hline 7 & $\begin{array}{l}\text { "Analisis Kelayakan Bisnis Pupuk Organik CV. } \\
\text { Dimas Jaya Kecamatan Bilah Hulu Kabupaten } \\
\text { Labuhanbatu Sumatera Utara" (Ginting, 2020) }\end{array}$ & $\begin{array}{l}\text { Hasil analisis menunjukkan bahwa usaha pupuk } \\
\text { organik CV. Dimas Jaya layak untuk dijalankan dengan } \\
\text { pendapatan Rp 240,847,325-per bulan, B/C ratio } \\
\text { sebesar 5.69 lebih besar dari } 1 \text { dengan payback period } \\
\text { selama 2,1 tahun }\end{array}$ \\
\hline
\end{tabular}

Dari beberapa data pendukung yang didapat, dapat disimpulkan bahwa hampir setiap tahun selalu ada pembahasan mengenai pembuatan pupuk organik cair dari bahan berbagai jenis ikan yang awam ditemui dan studi kelayakan bisnis pada usaha pupuk organik cair. Sehingga dapat dipastikan bahwa topik ini selalu mengalami pembaruan dan berkembang seiring waktunya. 


\section{METODOLOGI}

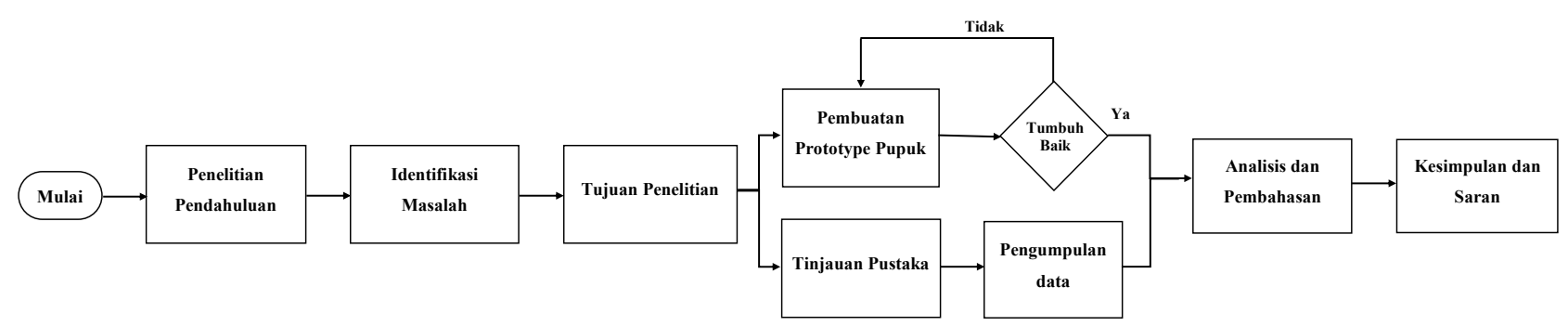

Gambar 1. Diagram Alir Metode Penelitian

Metode penelitian diawali dengan melakukan penelitian pendahuluan berupa observasi pada portal berita dan jurnal ilmiah serta berita mengenai kondisi pertanian untuk mengetahui kondisi terkini. Dilanjutkan dengan merumuskan masalah dan tujuan penelitian. Lalu mencari tinjauan atau kajian pustaka sebagai sumber teori dalam mengerjakan laporan tugas akhir, diikuti dengan pembuatan prototype pupuk organik cair. Prototype dapat dikatan berhasil apabila tumbuhan yang dijadikan sampel penelitian tumbuh dengan baik. Apabila tidak tumbuh dengan baik, maka perlu melakukan formulasi ulang pada pembuatan prototype pupuk. Selanjutnya, melakukan pengumpulan dan pengolahan data berupa: pada aspek pasar dan pemasaran, data yang dikumpulkan adalah voice of customer dengan menyebarkan kuesioner. Pertanyaan disebar kepada komunitas pertanian yang ada di platform facebook selama 10 hari pengambilan data. Kondisi demand \& supply, peluang bisnis, dan persaingan didapat dengan melakukan riset pasar pada e-commerce, situs resmi perusahaan, jurnal statistik, portal berita, dan lain-lain. Pada aspek teknis dan operasional, data yang dikumpulkan berupa bahan baku, harga dan tempat untuk mendapatkan bahan baku, penentuan lokasi bisnis, data alat dan teknologi yang dibutuhkan dan proses pembuatan pupuk organik cair dari limbah ikan lemuru, serta tata cara dalam melakukan pemasaran secara online melalui e-commerce. Pada aspek hukum \& manajemen, data yang dikumpulkan mencakup informasi bentuk usaha dan terbentuknya badan usaha mulai dari logo, visi \& misi, struktur organisasi dan sebagainya. Sedangkan data pada aspek keuangan, terdiri dari berapa lama proyek dijalankan, besar modal yang dikeluarkan, dan asumsi-asumsi peningkatan seperti inflasi, gaji pekerja dan lainnya. Dilanjutkan dengan membuat kesimpulan dan saran untuk menjawab tujuan permasalahan yang ada.

\section{HASIL DAN DISKUSI}

\section{A. Aspek Pasar \& Pemasaran}

Analisis demand menunjukkan bahwa setiap tahunnya permintaan masyarakat tani terhadap kebutuhan pupuk organik terus mengalami peningkatan. Unutk kuartal 1 tahun 2020 menunjukkan peningkatan sebesar $17,73 \%$ dilansir dari situs pupuk indonesia. Supply menunjukkan bahwa dari total produksi pupuk organik pada empat perusahaan BUMN yakni 2,195 juta ton, terdapat permintaan yang sangat tinggi untuk dipenuhi yakni 23 juta ton pupuk organik per tahun 2021. Berdasarkan riset pasar yang dilakukan dengan menyebar kuesioner, dapat diambil kesimpulan bahwa tingkat kesadaran konsumen terhadap produk pupuk organik cair berbahan dasar ikan masih terbilang kecil. Pemenuhan pupuk organik cair dari perusahaan bukan BUMN dapat sedikit banyaknya membantu untuk menyediakan hingga ratusan ribu ton per tahun, namun belum dapat menutupi kekurangan yang ada. Tingkat kesadaran konsumen terhadap penggunaan bahan dasar limbah ikan lemuru sangatlah rendah. Produk pupuk organik cair OCIAN berbahan dasar limbah ikan lemuru. Limbah yang digunakan adalah jeroan dan insang yang tidak digunakan pada usaha ikan kering yang terdapat di sepanjang area jalan nasional wilayah Situbondo yang langsung bersebelahan dengan garis pantai. Mengacu pada penelitian hasil pembuatan produk ikan lemuru dengan 80\% tingkat kemiripan bahan baku, kandungan NPK yang dimiliki adalah N 21g/L, P 7,3 g/L, dan K sebesar 13g/L. Pada hasil kuesioner bagian profil responden, dapat disimpulkan bahwa pengguna pupuk organik cair tidak hanya dari kalangan masyarakat tani saja. Namun, pengguna pupuk organik cair masih belum familiar dengan produk pupuk organik cair berbahan dasar ikan. Hal ini mengacu pada hasil kuesioner untuk pertanyaan 12 mengenai kesadaran konsumen terhadap penggunaan ikan sebagai bahan baku pembuatan pupuk organik cair. Terdapat 
80 dari 137 responden yang mengaku belum mengetahui pupuk organik cair dapat dibuat dengan bahan ikan. Didukung dengan hasil kuesioner pada pertanyaan 13 mengenai jenis ikan yang dapat dijadikan bahan baku, hanya terdapat 63 responden yang mengetahui jenis ikan yang dapat dijadikan pupuk organik cair. Dan pada pertanyaan 14 mengenai kesadaran terhadap penggunaan ikan lemuru sebagai bahan baku pupuk organik cair, terdapat 132 dari 137 responden yang mengaku tidak mengetahui ikan lemuru dapat dijadikan bahan pupuk organik cair. Setelah mengetahui tingkat kesadaran konsumen terhadap pupuk organik cair ikan lemuru, dapat disimpulkan bahwa pupuk organik cair dari ikan lemuru merupakan produk baru yang tidak ada di pasar. Produk POC dari ikan lemuru merupakan tangible product, artinya produk merupakan barang nyata yang memiliki bukti fisik. Produk usaha pupuk organik cair ikan lemuru dapat diklasifikasikan sebagai convenience product. Dapat dilihat dari karakteristik yang dimiliki seperti, pembelian dapat dilakukan dalam frekuensi tertentu, membutuhkan sedikit perencanaan, minimnya keterlibatan konsumen pada proses pembuatannya, harga yang relatif rendah, jalur distribusi yang luas dengan lokasi penyebaran yang sesuai dengan kebutuhan konsumen, dan mayoritas promosi dilakukan oleh produsen. Kegiatan promosi yang dilakukan adalah dengan melakukan penetrasi secara langsung kepada para petani secara langsung maupun melalui media sosial. Secara langsung, langkah yang dapat diambil adalah dengan memberikan contoh produk untuk digunakan langsung sehingga petani dapat langsung melihat efek yang dihasilkan terhadap tanaman yang digarap. Selain itu, dapat juga dilakukan pendekatan pada toko retail produk pertanian untuk dapat menempatkan produk pupuk organik cair dari limbah ikan lemuru sehingga dapat lebih banyak dikenal di kawasan regional tempat produksi berlangsung. Secara daring, kegiatan promosi yang dapat dilakukan adalah dengan cara memberikan penawaran berupa promo gratis ongkos kirim apabila memesan di marketplace seperti contoh Shopee dengan ketentuan, memenuhi jumlah kuota minimal pembelian dan jarak maksimal yang telah ditentukan oleh perusahaan.

Harga jual yang pada pupuk organik cair ikan lemuru untuk ukuran 1 liter adalah sebesar Rp 25,000. Harga tersebut didapat berdasarkan beberapa faktor yang terdiri dari hasil perhitungan HPP, hasil kuesioner pada pertanyaan 17 sampai 20 untuk biaya pembelian pupuk organik cair berdasarkan setiap ukuran pembelian, dan hasil kuesioner pada pertanyaan 21 sampai 24 mengenai biaya yang mau konsumen keluarkan untuk membeli pupuk organik cair ikan lemuru. Harga yang ditetapkan lebih tinggi dari hasil perhitungan HPP yang dinilai terlalu rendah. Hal ini bertujuan untuk menjaga kestabilan harga produk sehingga tidak merusak pasar yang ada. Place yang dimaksud pada bauran pemasaran adalah jalur distribusi produk. Mengacu pada hasil kuesioner pertanyaan 28, strategi distribusi yang dilakukan pada bisnis pupuk organik ikan lemuru berupa strategi insentif dan strategi selektif. Yang dimaksud strategi insentif adalah dengan melakukan pengedaran secara retail pada toko-toko pertanian untuk menyediakan menyediakan produk pada wilayah tertentu. Sedangkan yang dimaksud dengan strategi selektif adalah dengan menyalurkan produk melalui marketplace yang dipilih. Berdasarkan kedua strategi yang digunakan, proses distribusi yang dilakukan berupa $\mathrm{B} 2 \mathrm{~B} 2 \mathrm{C}$ atau business to business to customer dan $\mathrm{B} 2 \mathrm{~B}$ atau business to business.

Sedangkan proses distribusi yang digunakan terdapat pada channel level: consumer channel. Tidak hanya berperan dalam kegiatan produksi, namun juga berperan dalam proses penjualan hingga produk sampai pada konsumen. Selain terjun langsung untuk mengenalkan produk kepada petani sekitar tempat produksi pupuk organik cair, penyampaian bentuk informasi penjualan pupuk organik ikan lemuru berupa gambar dengan deskripsi produk menurut hasil kuesioner pertanyaaan 29. Sehingga media penyampaian informasi produk yang dipilih adalah brosur. Brosur tersebut nantinya akan disebar pada komunitas pertaninan organik melalui media sosial yang terdaftar seperti facebook dan sejenisnya. Sedangkan promo yang ditawarkan berupa gratis ongkos kirim untuk konsumen di area kabupaten yang sama dengan pembelian produk dengan jumlah tertentu.

Target pasar berasal dari kalangan pelaku tani dan perkebunan serta individu yang sedang melakukan kegiatan bercocok tanam. Produk dapat digunakan oleh individu dari segala usia, dengan catatan sudah memiliki pengetahuan mengenai produk pupuk. hal tersebut dilakukan agar produk dapat dijangkau oleh segala kalangan dengan berfokus pada pelaku tani dan perkebunan yang memiliki tingkat kebutuhan yang tinggi terhadap produk pupuk khususnya pupuk organik cair. Target pasar usaha Pupuk Organik Cair ikan lemuru merupakan kumpulan individu yang memiliki kebutuhan atau karakteristik yang sama, dari segala kalangan mulai dari ekonomi menengah ke bawah maupun menengah ke atas. Target pasar yang dituju juga merupakan individu yang berkeinginan untuk sekedar mencari alternatif POC maupun beralih dari pupuk non organik. Pupuk organik cair ikan lemuru menyasar konsumen pada tingkat produksi kecil, menengah, 
dan besar. Hal ini dilakukan untuk membangun brand image produk yang murah namun berkualitas dan ramah lingkungan dengan mendaur ulang limbah ikan yang ada.

\section{B. Aspek Teknis \& Operasional}

Pada aspek teknis dan operasional, dibahas mengenai tahap pembuatan pupuk organik cair ikan lemuru. Dimulai dari tahap formulasi menggunakan bahan-bahan seperti limbah jeroan ikan lemuru, tetes tebu, mikroorganisme EM4 dan air kelapa. proses pembuatannya dimulai dari pengecekan bahan baku, menyiapkan dan mencampur bahan baku, mencampur limbah jeroan ikan lemuru, tetes tebu, EM4 dan air kelapa. dilanjutkan dengan proses fermentasi selama 15 hari hingga produk siap untuk dikemas. Sebelum dipasarkan, dilakukan uji coba untuk melihat seberapa efektif hasil pupuk organik cair yang telah dibuat. Uji coba dilakukan pada 3 jenis tanaman yakni pokcoy, kangkung dan tomat. Proses pembuatan dan efek yang dihasilkan adalah sebagai berikut:
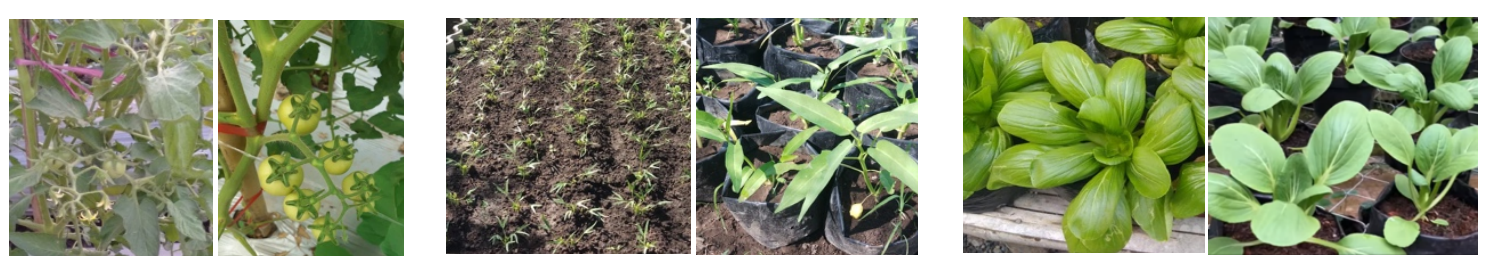

Gambar 2. Perbandingan hasil tanaman tanpa (kiri) dan menggunakan pupuk organik cair ikan lemuru (kanan)

Tabel 2

Efek Penggunaan Pupuk Organik Cair Ikan Lemuru

\begin{tabular}{|c|c|}
\hline Jenis tumbuhan & Efek yang dihasilkan \\
\hline Pokcoy & Daun lebih lebat \\
\hline Kangkung & Jumlah daun lebih banyak dan batang yang lebih tinggi \\
\hline Tomat & Buah sedikit lebih besar dan lebih cerah \\
\hline
\end{tabular}

Bahan baku yang dibutuhkan terbilang cukup mudah untuk didapat. Suplai bahan baku yang tersedia juga cukup melimpah, dapat dilihat dari jumlah tempat pengepulan ikan dan jumlah tempat produksi rumahan untuk pengolahan produk ikan di Situbondo. Terdapat banyak titik usaha yang dapat dijadikan sebagai rekan bisnis untuk menyediakan bahan baku utama pembuatan pupuk organik cair dari limbah ikan lemuru. Jumlah suplai dapat terpengaruh secara tidak signifikan dikarenakan jumlah penyuplai dan faktor yang mempengaruhi jumlah suplai jarang terjadi. Faktor yang dapat berpengaruh adalah kondisi alam dimana sepinya hasil tangkap yang biasanya terjadi paling lama 3-7 hari. Namun, anomali tersebut cukup jarang terjadi.

Untuk penentuan lokasi usaha, tempat yang digunakan adalah bangunan pribadi berukuran $12 \times 8 \mathrm{~m}^{2}$ sehingga dapat mengurangi biaya sewa. Sebagai gantinya, biaya yang perlu dikeluarkan adalah biaya renovasi untuk membuat bangunan layak untuk digunakan kembali. Tempat yang dipilih juga dekat dengan lokasi untuk mendapat bahan baku dan dikelilingi oleh area persawahan dan lingkungan tani. Sehingga lebih mudah untuk mendapatkan feedback dari para petani sekitar mengenai produk yang dipasarkan. Dalam prosesnya, tata letak bangunan yang digunakan akan dibagi menjadi tiga tempat, yakni tempat produksi, gudang bahan baku, dan gudang barang jadi. Layout bangunan yang digunakan dapat dilihat pada gambar berikut: 


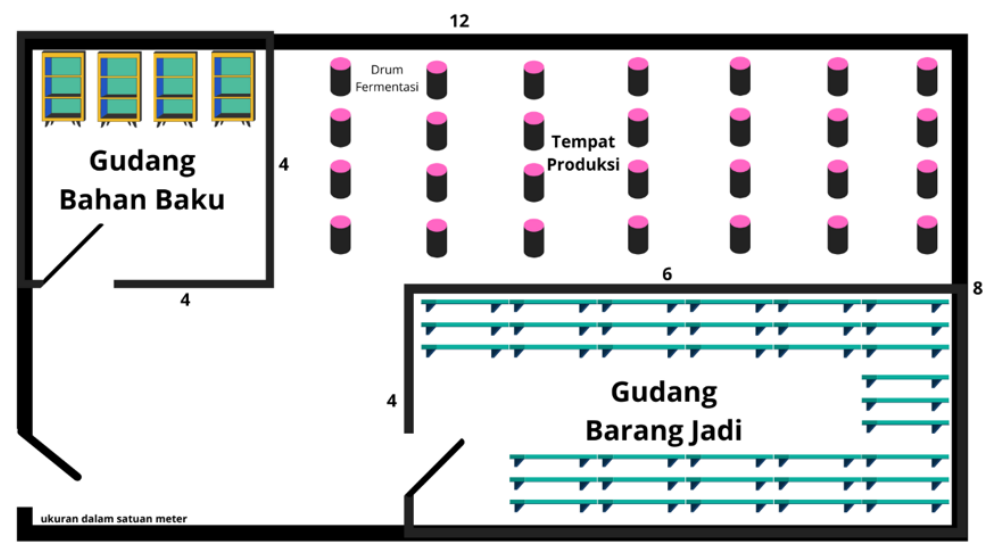

Gambar 3. Layout Bangunan Produksi Berskala 1:1

Dalam melakukan kegiatan produksi, dibutuhkan perlengkapan seperti drum air berukuran 150 liter, tongkat kayu untuk mengaduk, capping machine untuk menyegel kemasan bertipe DK-50Z, dan sebagai penunjang proses penjualan dibutuhkan laptop, smartphone, dan koneksi internet yang stabil untuk menunjang kegiatan operasional. Berikut adalah BOM pada pembuatan satu unit pupuk organik cair berukuran 1 liter:

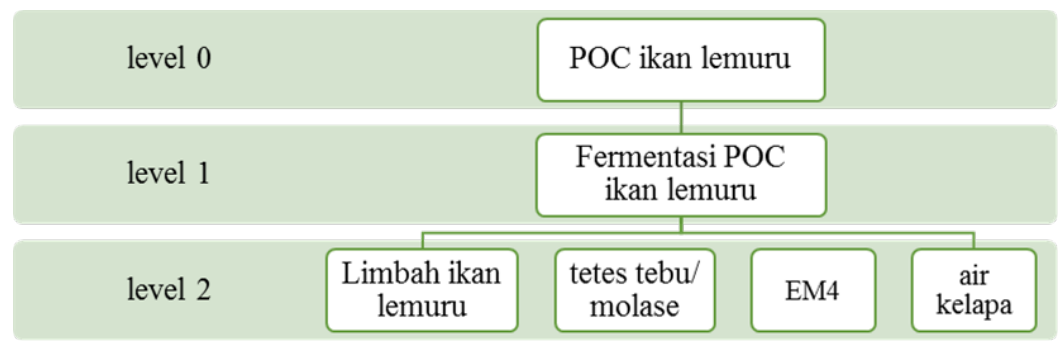

Gambar 4. Bill of Material 1 Unit Pupuk Organik Cair Ikan Lemuru

Proses produksi yang terjadi pada pembuatan pupuk organik cair berbahan dasar limbah ikan lemuru tidak terlalu rumit. Antara lain:

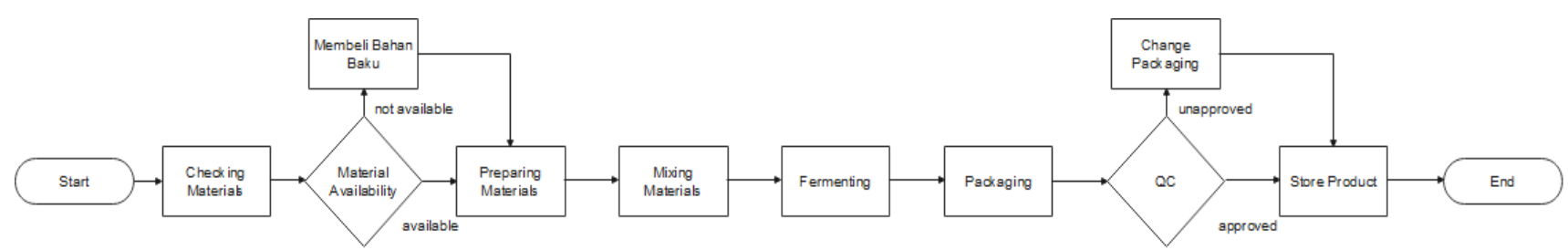

Gambar 5. Flowchart Proses Produksi Pupuk Organik Cair Ikan Lemuru

Pertama, dilakukan pengecekan bahan baku untuk melihat ketersediaan yang dimiliki. Apabila baha baku cukup maka dapat melanjutkan ke proses menyiapkan bahan baku. Apabila bahan baku tidak tersedia, maka perlu dilakukan pemesanan bahan baku terlebih dahulu. Setelah bahan baku siap, selanjutnya campur bahan baku pada wadah untuk selanjutnya dilakukan fermentasi selama kurang lebih 15 hari. Setelah siap, selanjutnya pupuk organik cair akan dikemas untuk dapat disimpan di gudang sebelum dipasarkan. Sebelum dimasukkan ke dalam gudang, perlu dilakukan pengecekan kualitas untuk melihat apakah ada kebocoran pada kemasan atau cacat lainnya. 


\section{Aspek Hukum \& Manajemen}

Bentuk usaha pada bisnis yang akan dijalankan adalah persekutuan komanditer (CV). Bentuk usaha ini dipilih karena merupakan alternatif pilihan bagi calon pelaku usaha yang ingin melakukan kegiatan usaha dengan modal yang terbatas. Langkah pendirian bisnis pupuk organik cair berbentuk CV antara lain, menentukan pihak yang berperan sebagai pendiri $\mathrm{CV}$, menyiapkan data pendirian $\mathrm{CV}$, membuat akta pendirian melalui notaris, penandatanganan akta oleh para pendiri CV, mengurus SKDP (Surat Keterangan Domisili Perusahaan) di kelurahan tempat pendirian CV, mengurus NPWP melalui kantor pelayanan pajak, mendaftar ke pengadilan negeri yang berwenang di daerah pendirian $\mathrm{CV}$, mengurus izin usaha di kantor pelayanan terpadu satu pintu (PTSP), mengurus tanda daftar perusahaan dan terakhir mengumumkan ikhtisar resmi.

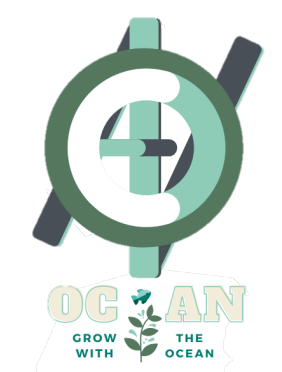

Gambar 6. Logo Bisnis (OCIAN)

OCIAN berasal dari kata ocean yang berarti lautan, mencerminkan produk kami yang berbahan dasar limbah jeroan ikan laut. Terdapat gambar tumbuhan dan ikan di tengah kata ocian yang melambangkan fungsi produk, yakni membantu pertumbuhan tanaman menggunakan pupuk berbahan dasar ikan. Memiliki slogan berupa "grow with the ocean" yang berarti tumbuh bersama lautan. Struktur organisasi OCIAN terdiri dari:

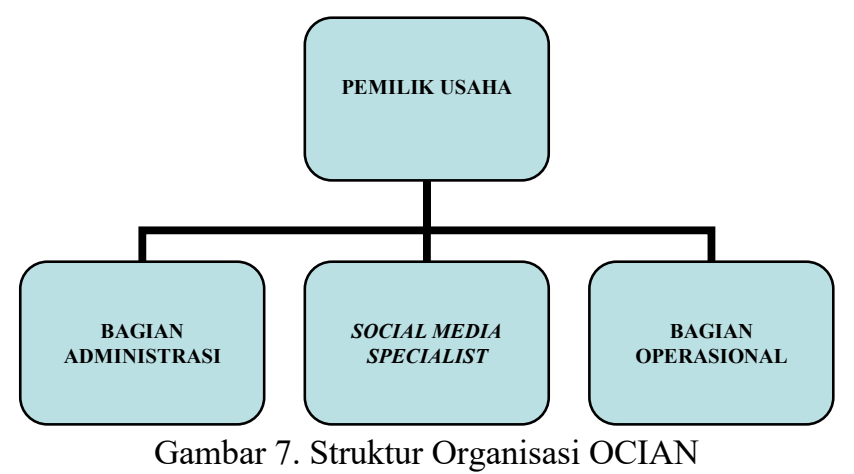

Tabel 3

Kebutuhan Awal Pekerja Bisnis Pupuk Organik Cair Ikan Lemuru

\begin{tabular}{|c|c|c|}
\hline Pekerjaan & Jumlah Pekerja & Spesifikasi Pekerjaan \\
\hline Administrasi & 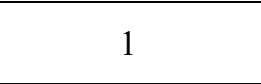 & $\begin{array}{ll}\text { a. } & \text { komunikasi } \\
\text { b. } & \text { pembukuan }\end{array}$ \\
\hline $\begin{array}{l}\text { Social media } \\
\text { specialist }\end{array}$ & 1 & $\begin{array}{ll}\text { a. } & \text { storytelling } \\
\text { b. } & \text { copywriting } \\
\text { c. } & \text { desain grafis } \\
\end{array}$ \\
\hline Operasional & 3 & a. Pengetahuan mengenai POC \\
\hline
\end{tabular}


Dasar pembentukan dari struktur organisasi yang terdapat pada usaha pupuk organik cair (POC) ikan lemuru OCIAN didasari oleh fungsi dari setiap bagian. Bagian administrasi berfungsi untuk melakukan pengecekan pasokan barang dan melakukan penjualan. Bagian operasional berfungsi untuk melakukan produksi, melakukan pengadaan suplai bahan baku dan pengawasan fermentasi pupuk setiap hari kecuali hari libur. Dan bagian social media specialist yang mengurus segala keperluan yang terkait pada promosi atau penjualan di sosial media. Jumlah tenaga kerja yang dibutuhkan untuk menjalankan proses operasional adalah sebanyak 5 orang, namun tidak menutup kemungkinan untuk menambah pekerja apabila terjadi lonjakan permintaan yang berada di luar perhitungan.

\section{Aspek Keuangan}

Faktor penentu untuk meyakinkan pemodal atau pelaku usaha untuk memulai bisnis adalah dengan melihat hasil penilaian investasi untuk melihat apakah bisnis yang dipilih memang layak untuk dijalankan dan akan mengalami keuntungan. Biaya yang masuk dalam perhitungan antara lain modal usaha, biaya bahan baku, biaya tenaga kerja, biaya renovasi pabrik, biaya promosi, biaya peluncuran usaha, biaya hosting website, biaya alat dan mesin, pajak, dan biaya pengiriman. Selain perhitungan biaya, juga digunakan asumsi untuk membantu perhitungan antara lain peningkatan kenaikan gaji pekerja, suku bunga pinjaman, inflasi, faktor risiko, kenaikan penjualan, kenaikan biaya utilities, dan waktu pengadaan barang.

Tabel 4

Data Asumsi pada Aspek Keuangan

\begin{tabular}{|l|c|c|l|}
\hline \multicolumn{1}{|c|}{ Asumsi } & Satuan & Nilai & \multicolumn{1}{c|}{ Sumber } \\
\hline Kenaikan gaji pekerja & $\%$ per tahun & 8 & Data UMR Situbondo 2020-2021 \\
\hline Suku bunga pinjaman & $\%$ per tahun & 6 & PT Bank Rakyat Indonesia (Persero) Tbk \\
\hline Kenaikan inflasi & $\%$ & 2,88 & Kemenkeu \\
\hline Peningkatan penjualan & $\%$ & 7,8 & Kementrian Perindustrian \\
\hline Kenaikan biaya bahan baku & $\%$ & 22,5 & Wawancara dengan vendor \\
\hline Faktor risiko & $\%$ & 5 & Peneliti \\
\hline Kenaikan biaya utilities & $\%$ & 13 & Kementrian ESDM \\
\hline
\end{tabular}

Tabel 5

Komponen Biaya pada Perhitungan Aspek Keuangan

\begin{tabular}{|c|l|c|}
\hline No & \multicolumn{1}{|c|}{ Nama Komponen } & Nilai (Rupiah) \\
\hline 1 & Modal Bisnis & $100,000,000$ \\
\hline 2 & HPP/ Harga Jual & 25,000 \\
\hline 3 & Biaya Operasional & 2,88 \\
\hline 4 & Bahan Baku & 55,500 \\
\hline 5 & Tenaga Kerja & 10,500 \\
\hline 6 & Promosi (X-banner \& Facebook) & 660,000 \\
\hline 7 & Peluncuran Usaha & $5,500,000$ \\
\hline 8 & Website hosting & 84,816 \\
\hline 9 & Biaya Percobaan & 109,000 \\
\hline 10 & Alat \& mesin & $15,643,200$ \\
\hline
\end{tabular}

Setelah melakukan perhitungan dibantu dengan menggunakan software Ms. Excel, hasil yang ditunjukkan adalah: 
Tabel 6

Lampiran Cashflow untuk Penilaian Investasi

\begin{tabular}{|c|c|c|}
\hline Tahun & Total & Total Cumulative \\
\hline 0 & $-R p 110,163,200$ & $-R p 110,163,200$ \\
\hline 1 & $\mathrm{Rp} 450,621,930$ & $\mathrm{Rp} 340,458,730$ \\
\hline 2 & $\mathrm{Rp} 613,886,818$ & $\mathrm{Rp} 954,345,548$ \\
\hline 3 & $\mathrm{Rp} 635,275,124$ & $\mathrm{Rp} 1,589,620,672$ \\
\hline 4 & $\mathrm{Rp} 739,865,857$ & $\mathrm{Rp} 2,329,486,529$ \\
\hline 5 & $\mathrm{Rp} 844,539,204$ & $\mathrm{Rp} 3,174,025,733$ \\
\hline
\end{tabular}

\begin{tabular}{|c|c|}
\hline IRR & $\mathbf{4 3 7 . 8 3 \%}$ \\
\hline MARR & $\mathbf{3 4 . 5 6} \%$ \\
\hline NPV & Rp754,052,861 \\
\hline
\end{tabular}

Nilai IRR $>$ MARR artinya bisnis layak untuk dijalankan. Nilai NPV $>0$ maka bisnis layak dijalankan. Dan payback period menunjukkan bahwa pada tahun pertama bulan maret sudah mendapatkan keuntungan.

\section{KESIMPULAN}

1. Berdasarkan hasil pada aspek-aspek penilaian bisnis, didapat hasil berupa: pada aspek pasar \& pemasaran, kondisi pasar pupuk organik masih terbuka lebar. Tingginya permintaan dan masih minimnya tingkat pemenuhan, menjadi kendala utama. Namun, dengan terus naiknya permintaan pupuk organik setiap tahunnya menjadi salah satu indikasi pendukung bahwa bisnis berpeluang untuk dijalankan. Produk dapat dipasarkan kepada konsumen melalui daring dan retail kepada petani tanaman organik. Tingkat persaingan pada pupuk organik cair berbahan ikan relatif minim, sehingga memperlebar kesempatan perkembangan bisnis untuk mencapai konsumen baru. Harga jual yang ditetapkan adalah sebesar Rp 25,000 dengan memperhatikan harga pasar yang ada. Pada aspek teknis \& operasional, hasil ujicoba produk menunjukkan hasil positif dimana dampak yang ditimbulkan oleh penggunaan pupuk organik cair dari bahan limbah ikan lemuru menghasilkan daun yang lebih lebat, batang yang lebih tinggi, dan buah yang diperoleh relatif lebih besar dan lebih cerah. Bangunan sebagai tempat produksi menggunakan bangunan pribadi berukuran $12 \times 8 \mathrm{~m}^{2}$ dengan beberapa ruang yakni ruang produksi, gudang bahan baku, dan gudang barang jadi. Mesin yang digunakan adalah mesin capping untuk menyegel kemasan pupuk organik cair. Pada aspek hukum dan manajemen dijelaskan langkah pendirian CV, struktur organisasi bisnis terdiri dari admin, social media specialist, dan pekerja operasional dengan jumlah kebutuhan karyawan pada awal pendirian sebanyak 5 orang. Sedangkan pada aspek keuangan hasil yang didapat adalah komponen-komponen yang termasuk dalam perhitungan biaya, asumsi yang digunakan untuk menghitung flowchart selama 5 tahun dan penilaian investasi yang menunjukkan hasil berupa IRR sebesar 473,83\% > MARR 34,56\%, dan nilai NPV > 0 yakni sebesar Rp 754,052,861.

2. Untuk penelitian selanjutnya, dapat diusulkan untuk menambahkan kriteria penilaian yakni aspek lingkungan hidup dan aspek lingkungan industri sehingga dapat lebih menyempurnakan penilaian yang dilakukan.

\section{DAFTAR PUSTAKA}

Ali, M., Nisak, F., \& Ika Pratiwi, Y. (2020). Pemanfaatan Limbah Cair Ikan Tuna Terhadap Pertumbuhan Tanaman Pakchoy Dengan Wick System Hydroponik. Agro Bali: Agricultural Journal, 3(2), 186-193. https://doi.org/10.37637/ab.v3i2.616

Apiat, A., \& Dinar. (2016). Analisis Kelayakan Usaha Pupuk Organik (Studi Kasus Rumah Kompos di Gapoktan Suka Hasil Desa Cintaasih Kecamatan Cingambul). Agrivet Jurnal, 4(2), 167-180. 
Badan Pusat Statistik. (2017). Impor Pupuk Menurut Negara Asal Utama. 12, 2008-2009. https://www.bps.go.id/staticable/2014/09/08 /1044//impor-pupuk-menurut-negara-asalutama-20002016.html

Badan Pusat Statistik. (2019). Statistik Perikanan Provinsi Jawa Timur.

Dinas Tanaman Pangan, H. dan P. S. (2020). Profil Dinas TPHP. Journal of Chemical Information and Modeling, 53(9), 1689-1699.

Durri, A., Saifi, M., \& Azizah, D. (2016). Analisis Kelayakan Usaha dalam Rangka Rencana Pengembangan Usaha (Studi Kasus Pada PO. Zena Pariwisata Malang). Jurnal Administrasi Bisnis S1 Universitas Brawijaya, 35(2), 174-180.

Ginting, F. A. (2020). Analisis kelayakan usaha pupuk organik cv. dimas jaya kecamatan bilah hulu kabupaten labuhanbatu sumatera utara skripsi.

Karthika Priyadhardshini Jayamala A. K., R. L. B. L. P. N. N. K. T. (2018). Studi Kelayakan Bisnis. International Journal of Physiology, 6(1), 2018.

Meritasari, D., Mubarok, A. S., Sulmartiwi, L., \& Masithah, E. D. (2012). Pengaruh Pemberian Pupuk Cair Limbah Ikan Lemuru (Sardinella sp.) Dengan Dosis Yang Berbeda Terhadap Pertumbuhan Chlorella sp. Jurnal Ilmiah Perikanan Dan Kelautan, 4(1), 27-32. https://ejournal.unair.ac.id/JIPK/article/view/11579

Organic Institute, Y. A. dan K. i. (2019). Statistik Pertanian Organik Indonesia 2019. In Journal of Chemical Information and Modeling (Vol. 53, Issue 9).

Pardani, C., \& Sutriana, D. (2018). Analisis Kelayakan Usaha Pupuk Organik (Po) Curah. MIMBAR AGRIBISNIS: Jurnal Pemikiran Masyarakat Ilmiah Berwawasan Agribisnis, 1(3), 203. https://doi.org/10.25157/ma.v1i3.40

Pasta, K., Ikan, D., Tawar, A. I. R., \& Laut, P. D. A. N. (2014). Jurnal Pengolahan dan Bioteknologi Hasil Perikanan. 3(2003), 75-81.

Pertanian, F., Muhammadiyah, U., \& Utara, S. (2019). Analisis Kelayakan dan Strategi Pengembangan Usaha Pupuk Organik (Studi Kasus: Desa Mekar Sari, Kecamatan Pulau Rakyat, Kabupaten Asahan, Propinsi Sumatera Utara).

Piri, G. A. M. M. (2017). Pembuatan Pupuk Cair Dari Limbah Pengolahan Ikan Tradisional. Jurnal Envirotek, $9(2)(2), 0-4$.

Purnomo, R. A., Riawan, \& Sugianto, L. O. (2017). Studi Kelayan Bisnis. In Jurnal Universitas Muhammadiyah Ponorogo.

Risnayanti, C. (2010). Analisis Kelayakan Usaha Mikro Pupuk Organik.

Suartini, K., Abram, P. H., \& Jura, M. R. (2018). Pembuatan Pupuk Organik Cair dari Limbah Jeroan Ikan Cakalang (Katsuwonus pelamis). Jurnal Akademika Kimia, $7(2), \quad 70$. https://doi.org/10.22487/j24775185.2018.v7.i2.10396

Wahyuniardi, R., \& Eeng, S. (2014). Studi Kelayakan Pendirian Industri Kecil Pupuk Organik Padat dan Cair Berbahan Baku Limbah Perkebunan, Peternakan dan Industri. Jurnal Ilmiah Teknik Industri, 2(2), 101-108.

Zulkarnaini, A., \& Yuniar Saleh, A. (2014). Analisis Kelayakan Pembangunan Usaha Pupuk Organik di Provinsi Lampung. Jurnal Online Institut Teknologi Nasional, 01(03), 243-253. https://ejurnal.itenas.ac.id/index.php/rekaintegra/article/viewFile/282/526 